\title{
The Effect of Islamic Self Esteem and Islamic Self Efficacy on Job Satisfaction with Productivity as Intervening Variables
}

\author{
Desna Fitriastuti Santoso ${ }^{1 *}$, and Iskandar ${ }^{1}$ \\ ${ }^{1}$ Fakultas Ekonomi dan Bisnis Islam, IAIN Salatiga, Indonesia.
}

\begin{abstract}
This study aims to determine the effect of Islamic self-esteem and Islamic self-efficacy on job satisfaction through productivity at Kampoeng Kopi Banaran Bawen. This study uses quantitative methods by processing primary data through several questionnaires given to employees of Kampoeng Kopi Banaran. The sample in the study was 40 respondents (saturated sample). The data obtained were processed with SPSS version 26. Based on the results of processing a questionnaire from 40 respondents. The results of the study show that: [1] Islamic self-esteem has a negative and significant effect on job satisfaction, [2] Islamic self-efficacy has a positive and significant effect [3] productivity has a positive and significant effect on job satisfaction, [4] Islamic self-esteem has a positive and significant impact on job satisfaction. significant effect on productivity, [5] Islamic selfefficacy has a negative and significant effect on productivity [6] productivity can mediate Islamic self-esteem on job satisfaction, [7] productivity can mediate Islamic self-efficacy on job satisfaction.
\end{abstract}

Keywords: Islamic self-esteem, Islamic self- efficacy, Job satisfaction, Productivity

\section{INTRODUCTION}

\subsection{Background}

One of the most important approaches for an organization is human resources itself including reasons, ideas and affiliations. In studying human resources, there are three approaches, namely mechanical, paternalist and social systems approaches. Faced with a rapidly changing environment, businesses must improve the effectiveness of their effective management and control systems to ensure a high degree of consistency between individuals and organizations. One of the steps is to pay attention to "the right man in the right place" which prioritizes an individual with character (Wibowo, 2015).

* Corresponding author: iskandarchang@iainsalatiga.ac.id 


\section{$A \mathrm{IC} \quad$ Annual International Conference \\ on Islamic Economics and Business, 2021}

The success of a company can also be assessed through one's job satisfaction, especially with the number of cases of declining company performance due to lack of job satisfaction for employees which can be fatal and detrimental. For example, factory workers who go on strike because of low wages then protest to increase their wages (Prawironegoro, 2001). As for those who think that an increase in job satisfaction can be created because of self-esteem (Sigiro, 2005).

Islamic Self Esteem is the main driver for character development. Based on the teachings of the Qur'an, consistent self-esteem rests on natural talent, determination, ability, and concern for self-potential, dignity, independence, and trust in God and His help by reducing hope and greed.

Islamic self-efficacy is a form of confidence. The concept of belief in Islam is faith (Jafaar \& Tamuri, 2012). Those who believe in their independence will not exaggerate their weaknesses when faced with failure, failure is a lesson that tells a person to get back up, which will not be repeated in the future, and vice versa. Their own efforts will not be claimed as a single struggle and success, just because they succeeded with the help of Allah SWT, this is because they believe that they are able to achieve the success permitted by Allah SWT (Ismail, 1998). Self-efficacy is high self-confidence in a person in order to achieve a good level of performance, measurement of clear goals, strong motivation, emotional stability, and performance competence for successful activities or personality, someone who has a level of self-efficacy low will look different. This person usually does not have more effort, or prefers to work together in a difficult environment and the high complexity of a task.

Productivity is very important for company management. One of the important factors when determining the results to be achieved by an organization is its human resources (Ravianto 1990) stated that productivity is a spiritual attitude of pride in work, based on a strong motivation to continue working towards a better quality of life. Improved quality of life is obtained when productivity increases. Companies basically want to get high productivity figures from their employees because of increased employee productivity, the company has high expectations of profits. (Sedarmayanti 2011) argues that productivity is a process in which people's knowledge of what is produced is higher than what has been obtained or used.

With so many employees at Kampoeng Kopi Banaran and with different individual characteristics, an employee's self-confidence is often a problem, namely the fear of learning new things. Likewise with the belief in himself that he cannot keep up with the abilities of other employees, therefore these obstacles result in not optimal productivity and job satisfaction of an employee (Iswati, 2021).

\subsection{Problem Formulation}

a. Is there an influence between Islamic self-esteem on job satisfaction?

b. Is there any influence of Islamic self-efficacy on job satisfaction?

c. Is there an influence between productivity on job satisfaction?

d. Is there any influence of Islamic self-esteem on productivity?

e. Is there any influence of Islamic self-efficacy on productivity?

f. Is there an effect of the Islamic self on job satisfaction mediated by productivity?

g. Is the influence of Islamic self-efficacy on job satisfaction mediated by productivity? 


\section{$A T C \overline{I E B} \quad$ Annual International Conference \\ on Islamic Economics and Business, 2021}

\subsection{Research Purposes}

Based on the formulation of the problem above, the purpose of this study is to answer questions related to Islamic self-esteem. Islamic self-efficacy, job satisfaction, and productivity.

\section{CONCEPTUAL FRAMEWORK}

\subsection{Grand Theory (Two factor theory)}

(Herzberg et al., 1958) stated that job satisfaction and dissatisfaction are contradictory things. How to determine how satisfied someone is can be seen from the motivational factors in him that he has. By using the two-factor theory there are two characteristics, namely dissatisfied / hygiene and satisfier/motivators. Disaster groups include salary, status, relationships between individuals, and working conditions. While the satisfier groups include awards, recognition, responsibility, promotion, and career development.

The two-factor theory provides an important contribution to the organization in encouraging employees to have good satisfaction and productivity. Intrinsically motivated employees will like their work which allows them to use their creativity and innovation, with that it will be enough to solve problems in companies that are quite common in the work environment.

\subsection{Islamic Self Esteem}

Islamic Self Esteem or self-esteem in Islam is explained in the Koran that self-esteem is also divided into positive and negative. Positive self-esteem, namely believers, obedience, Muslims, kind and sincere. Negative self-esteem includes pagans, evil, and idolaters. As the word of Allah SWT in (Surah 30: 4-6) "Indeed We have created humans in the best form. Then We returned him to the lowest (hell) place, except for those who believe and do righteous deeds; then for them a reward that never ends." Explanation of self-respect, which requires that the things created are maintained properly by maintaining faith, obeying, and staying away from actions that are prohibited by Allah SWT. 1976) :

There are several factors that can affect Islamic self-esteem according to (Coopersmith,

a. Acceptance

Where individuals feel accepted and valued in a group.

b. Confidence

Confidence in his ability to achieve a goal.

c. Valuable

Often individuals feel worthless, this involves a great sense of self-confidence that he matters.

Indicators in Islamic self-esteem according to (Coopersmith, 1976) are :
a. Strenght
b. Meaning
c. Competent
d. Policy 


\section{$A \mathrm{IC} \overline{I E B}$ Annual International Conference \\ on Islamic Economics and Business, 2021}

\subsection{Islamic Self Efficacy}

Word of Allah SWT in (Qs. 4: 139) 'do not be weak, and do not (also) be sad, even though you are the people of the highest (degree) if you are believers". The above verse emphasizes one's self-confidence. Self-efficacy is defined as a sense of confidence individuals will have the opportunity to successfully complete a particular job (Kreitner, 2010).

There are several factors that can affect Islamic self-efficacy according to (Raudatussalamah, 2014) are :
a. Experience Success
Success makes a person's self-confidence increase.
b. Experience of others
With good work experience, then someone will create success and it makes high self-efficacy.
c. Verbal persuasion
Individuals will be instructed to get guidance and advice so as to create an increase in confidence.
d. Psychological state
In order to avoid discomfort, anxiety and stress, a person is asked to remain positive about himself.

Indicators in Islamic self-efficacy according to (Raudatussalamah, 2014) are :
a. Dimensions Level ( level)
b. Dimensions of Strength (strength)
c. Dimensions of Generalization (Generality)

\subsection{Productivity}

Work productivity is a comparison between output and input, where the output must have more value as well as better work skills than before (Hasbuan \& Malayu, 2011). slam encourages its followers to synergize with all economic activities. Islam gives blessings to work in the world and makes it a jihad and a field of worship. The factors that affect productivity according to (Soemarso, 2004) are :
a. Top management
Support Support in the form of promoting entrepreneurial activity and providing the necessary resources.
b. Organizational structure productivity (objectives).
c. Creating a conducive corporate climate
Productivity will increase if it is supported by good climates
Support Provide support to the organizational structure to support increased
d. Productivity measurement methods
Companies need to develop methods to measure productivity and set targets to be realized.

The productivity indicators by (Sutrisno, 2014) are :
a. Ability
b. Trying to increase target
c. Work Spirit
d. Self-development 


\section{$A \mathrm{IC} \overline{I E B}$ Annual International Conference \\ on Islamic Economics and Business, 2021}

\subsection{Job Satisfaction}

Job satisfaction is a series of special attitudes possessed by members of an organization, and job satisfaction means effective stimulation by employees for their work (Winardi, 2001).

The factors that influence job satisfaction according to (Effendi, 2002) are :

a. Wages

Wages are defined as the right to financial benefits obtained by employees

b. Treatment of superiors

In order to have an equal opinion about the true meaning of justice, there must be open communication between the two.

c. Working environment conditions

They will feel easy and comfortable to complete their work if the environment is conducive

d. Promotion

Promotion is an incentive for employees with high performance, ambition and motivation.

The indicators that affect job satisfaction according to (Luthans, 2006) are :
a. Satisfaction with salary
b. Satisfaction with the work itself
c. Satisfaction with promotion
d. Satisfaction with coworkers

\subsection{Model Framework}

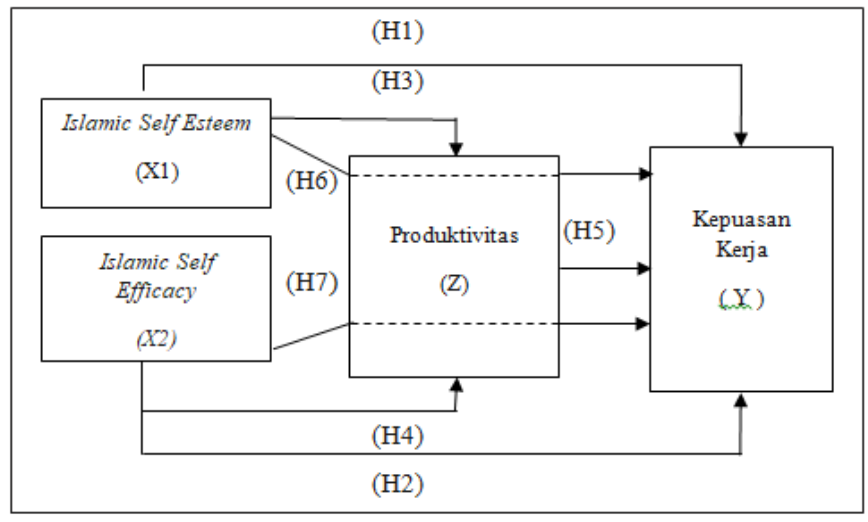

Fig.1 Model Framework

\section{Hypotesis :}

H1: Islamic self-esteem has a positive and significant effect on job satisfaction

$\mathrm{H}$ 2: Islamic self-efficacy has a positive and significant effect on job satisfaction

H3: Productivity has a positive and significant effect on job satisfaction

H4: Islamic self-esteem has a positive and significant effect on productivity.

H5: Islamic self-efficacy has a negative and significant effect on productivity

H6: Productivity is able to mediate Islamic self-esteem on job satisfaction

H7: Productivity is able to mediate Islamic self-efficacy on job satisfaction

\subsection{Research Methods}




\section{Type of Research}

Research This research uses quantitative research. Quantitative research is a type of research that can be obtained using statistical methods so as to produce new discoveries. The quantitative approach tends to certain phenomena that have characteristics in human life, which are called variables.

\section{Populations}

Is the object of research and all fields of research objects are determined by researchers to be analyzed and concluded (Bawono, 2006). In this study, the population in Kampoeng Kopi Banaran Bawen was 214 employees.

\section{Sample}

A sample is part or representative of the test population, if the test is part of the population, then the test can be considered as a test sample(Arikunto, 2006). he sample used in this study is a saturated sample with a total of 40 employees in which there are limitations and company permits.

\subsection{Data collection technique}

Data collection technique is a method in research to obtain the necessary data. This study uses a questionnaire. the method is a Questionnairelist of statements or questions written in research that must be answered by respondents.

\section{Test Instrument}

a. Validity Test

The test is used in the process of measuring whether the questionnaire is valid. A questionnaire that is declared valid is if the questions in the questionnaire are able to explain what will be measured in the questionnaire (Ghozali, 2009). To test the validity, the product-moment correlation test is used with the test criteria if the value of $r$ count $>r$ table and significance value $<0.05$ then the conclusion is the indicator is valid, and if the value of $r$ count $<\mathrm{r}$ table and significance value $>0.05$ then the conclusion is the indicator is not valid.

b. Reliability Test

The test refers to the understanding that the tool used, in order to obtain information used in research, can be used as a data collection tool and can reveal actual information (Sitinjak, 2006). Reliability testing was carried out using the Cronbach alpha test, with the test results criteria if the Cronbach Alpha value calculated $>0.6$ then the conclusion was the research variable was reliable, and vice versa.

\subsection{Classic Assumption Test}

1. Normality Test

The test has the aim of knowing if the data is normally distributed and independent (Ghozali, 2009).

2. Multicollinearity Test

The test is a condition where there is a perfect or near-perfect linear relationship between the independent variables in the regression model (Duwi, 2010). 


\section{$A I C \overline{I E B} \quad$ Annual International Conference \\ on Islamic Economics and Business, 2021}

3. Linierity Test

The test is used to prove whether the specifications of the model used are correct (Bawono, 2006).

4. Heteroscedasticity Test

The test has a purpose in testing the variance in the regression model is the same or not. If the mean square error, it can be called a good regression model. In this method, the test is used park, where the test is carried out through regression between independent variables and errors.

\subsection{Model Determination Test}

\section{T- test ( Partial )}

The test is carried out partially or individually for each independent variable using the $t$ statistical test with a certain level of confidence (Bawono, 2006).

2. F test

Used to determine whether the independent variables simultaneously have a significant effect on the dependent variable. The degree used is $5 \%$ or 0.05 . If the calculated $\mathrm{F}$ value $>\mathrm{F}$ table, it can be concluded that all independent variables simultaneously have a significant effect on the dependent variable (Ghozali, 2009).

3. Test $\mathrm{R}^{2}$ (coefficient and determination)

The coefficient of determination was essentially measured how much the level of relationship with the independent variable dependent variable (Bawono, 2006)

\subsection{Analysis Tool}

1. Path Analysis

The analysis is the use of regression analysis to estimate cause-and-effect relationships between predetermined variables (causal models) (Ghozali, 2009).

2. Sobel Test

Sobel test is a test to see the correlation in which the intervening variable can mediate the relationship significantly or not (Ghozali, 2009). To see whether the mediation effect is significant or not, it can be tested using the Sobel test, with the formula:

$\mathrm{S}_{\mathrm{ab}}=\sqrt{b^{2} s a^{2}+a^{2} s b^{2}+s a^{2} s b^{2}}$

Where:

$\mathrm{Sa}=$ standard error coefficient $\mathrm{a}$

$\mathrm{Sb}=$ standard error coefficient $\mathrm{b}$

$\mathrm{b}=$ coefficient of the mediating variable

$\mathrm{a}=$ coefficient of the independent variable

To test the significant effect of the mediating variable, it is necessary to calculate the $t$ value of the coefficient ab with the formula

$$
\mathrm{t}=\frac{a b}{S a b}
$$

Then from the results of these calculations, if the value of $t$ count $>t$ table with a significance of 0.05 , it can be concluded that the mediation variable is significant. 


\subsection{DISCUSSION AND RESULTS OF}

1. Validity test and Reabilitiy Test for Instrumen

Whether or not the indicators in the questionnaire are valid can be known by comparing the $r$ count and $r$ table. $r$ table can be calculated with a degree offreedom $(d f)=\mathrm{n}-2,(\mathrm{df})=40-2$, where $\mathrm{n}$ here is the total number of respondents, namely 38 people with a significance of $5 \%$, then the value of the $r$ table is 0.312 . The results of the data processing concluded that all the statement indicator items in the questionnaire had a calculated r-value greater than the $r$ table, so it can be said that the questionnaire in this study was valid.

Reliable or not the respondent's answer to the statement item can be known by comparison if the calculation of the value Cronbach alpha $>0.6$ then the statement is reliable, and vice versa.

Table 1. reability test

\begin{tabular}{|c|c|c|c|}
\hline No & Variabel & $\begin{array}{c}\text { Cronbach } \\
\text { Alpha }(a)\end{array}$ & Keterangan \\
\hline 1 & Islamic Self Esteem (X1) & 0,605 & Reliabel \\
\hline 2 & Islamic Self Efficacy(X2) & 0,842 & Reliabel \\
\hline 3 & Kepuasan Kerja (Y) & 0,614 & Reliabel \\
\hline 4 & Produktivitas (Z) & 0,608 & Reliabel \\
\hline
\end{tabular}

The results of the tests on the variables above which state that Cronbach's Alpha $(\alpha)$ is more than 0.6 , it can be concluded that the statement indicators in the questionnaire are consistent/reliable.

\section{Asumsi Klasik}

a. Normality Test

Tabel 2. Normality test

\begin{tabular}{|l|l|r|}
\hline \multicolumn{2}{|c|}{ One-Sample Kolmogorov-Smirnov Test } \\
\hline \multicolumn{2}{|c|}{} & $\begin{array}{r}\text { Unstandardiz } \\
\text { ed Residual }\end{array}$ \\
\hline $\mathrm{N}$ & Mean & 40 \\
\hline \multirow{3}{*}{ Normal Parameters } & .0000000 \\
\cline { 2 - 3 } & $\begin{array}{l}\text { Std. } \\
\text { Deviation }\end{array}$ & 1.46231400 \\
\hline Most Extreme Differences & Absolute & .094 \\
\cline { 2 - 3 } & Positive & .094 \\
\cline { 2 - 3 } & Negative & -.059 \\
\hline Test Statistic & .094 \\
\hline Asymp. Sig. (2-tailed) & $.200^{\circ ., 0}$ \\
\hline
\end{tabular}

a. Test distribution is Normal.

b. Calculated from data.

c. Lilliefors Significance Correction.

d. This is a lower bound of the true significance.

Sumber: data primer yang diolah, 2021 


\section{$A \mathrm{IC} \overline{I E B}$ Annual International Conference \\ on Islamic Economics and Business, 2021}

From the table it can be seen that the resulting significance value is 0.200. This means that it can be concluded that the residual distribution of the research data is normal because the significance value is $>0.05$.

b.Multikolonierity Test

Tabel 3

\begin{tabular}{|c|c|c|c|c|c|c|c|c|}
\hline \multicolumn{9}{|c|}{ Coefficients ${ }^{a}$} \\
\hline \multirow{3}{*}{\multicolumn{2}{|c|}{ Model }} & \multirow{2}{*}{\multicolumn{2}{|c|}{$\begin{array}{l}\text { Unstandardized } \\
\text { Coefficients }\end{array}$}} & \multirow{3}{*}{$\begin{array}{c}\text { Standardized } \\
\text { Coefficients } \\
\text { Beta }\end{array}$} & \multirow[t]{3}{*}{$\mathrm{T}$} & \multirow[t]{3}{*}{ Sig. } & \multirow{2}{*}{\multicolumn{2}{|c|}{$\begin{array}{l}\text { Collinearity } \\
\text { Statistics }\end{array}$}} \\
\hline & & & & & & & & \\
\hline & & $B$ & $\begin{array}{l}\text { Std. } \\
\text { Error }\end{array}$ & & & & Tolerance & VIF \\
\hline \multirow[t]{4}{*}{1} & (Constant) & 7.924 & 3.534 & & 2.242 & .031 & & \\
\hline & $\mathrm{X} 1$ & -.140 & .132 & -.108 & -1.056 & .298 & .977 & 1.023 \\
\hline & $\mathrm{X} 2$ & .029 & .089 & .033 & .326 & .746 & .977 & 1.023 \\
\hline & Z & .735 & .095 & .783 & 7.707 & .000 & .998 & 1.002 \\
\hline
\end{tabular}

Based on the table, it can be seen that all independent variables have a tolerance value $>0.1$ and a VIF value $<10$, which means that this regression model is free from the symptom of multicollinearity.

c. Heteroscedasticity Test

Tabel 4. Heteroscedasticity Test

Coefficients $^{\mathrm{a}}$

\begin{tabular}{|c|c|c|c|c|c|c|}
\hline \multirow{2}{*}{\multicolumn{2}{|c|}{ Model }} & \multicolumn{2}{|c|}{$\begin{array}{l}\text { Unstandardized } \\
\text { Coefficients }\end{array}$} & \multirow{2}{*}{$\begin{array}{c}\text { Standardized } \\
\text { Coefficients } \\
\text { Beta } \\
\end{array}$} & \multirow[t]{2}{*}{$\mathrm{t}$} & \multirow[t]{2}{*}{ Sig. } \\
\hline & & B & Std. Error & & & \\
\hline \multirow[t]{4}{*}{1} & (Constant) & -20.220 & 13.409 & & -1.508 & .140 \\
\hline & Lnx1 & 5.385 & 3.607 & .238 & 1.493 & .144 \\
\hline & Lnx2 & 1.847 & 1.831 & .161 & 1.009 & .320 \\
\hline & $\operatorname{Ln} \times 3$ & -.680 & 2.098 & -.052 & -.324 & .748 \\
\hline
\end{tabular}

Value of each variable is not significant, which is greater than 0.05 , it can be concluded that the regression model occurs homoscedasticity.

\subsection{Model Determination Test}

1. T-test ( Partial)

Model 1 (one) T-test can be concluded:

a. The constant 1.080 means that if the variables Islamic Self Esteem (X1), Islamic Self Efficacy (X2), Productivity (Z) are constant, the decision will increase by 1.080 or $1.08 \%$.

b. The coefficient of Islamic Self Esteem (X1) is 0.399 which means that every one additional point of Islamic Self Esteem (X1) will increase Job 


\section{$A \mathrm{IC} \overline{I E B}$ Annual International Conference \\ on Islamic Economics and Business, 2021}

Satisfaction (Y) by 0.399 times. It is concluded that Islamic Self Esteem (X1) has a positive effect on Job Satisfaction (Y).

c. The coefficient of Islamic Self Efficacy (X2) is 0.329 which means that every one additional point of Islamic Self Efficacy (X2) will increase Job Satisfaction (Y) by 0.329 times. It is concluded that Islamic Self Efficacy (X2) has a positive effect on Job Satisfaction (Y).

d. The Productivity Coefficient $(Z)$ is 1.030 which means that every one additional point of Productivity (Z) will increase Job Satisfaction (Y) by 1.030 times. So it is concluded that Productivity (Z) has a positive effect on Job Satisfaction (Y).

e. Islamic Self Esteem (X1) has a t-value of -2.153 and a significance value of 0.038 at a coefficient $(\alpha)$ of $5 \%$. Because of the value of sig. $<0.05$, it can be concluded that Islamic Self Esteem (X1) has a negative and significant effect on Job Satisfaction (Y).

f. Islamic Self Efficacy (X2) has a value of 2.061 and a significance value of 0.047, it is concluded that Islamic Self Efficacy (X2) has a positive and significant effect on Job Satisfaction (Y).

g. Productivity $(Z)$ has a value of 6.986 and a significance value of 0.000 , it is concluded that Productivity $(Z)$ has a positive and significant effect on Job Satisfaction (Y).

T-test model 2 (two) can be concluded:

a. Islamic Self Esteem (X1) has an at-value of 2.403 and a significance value of 0.021 at a coefficient $(\alpha)$ of $5 \%$. Because the significance value is $<0.05$, it can be concluded that Islamic Self Esteem (X1) has a positive and significant effect on Productivity $(\mathrm{Z})$

b. Islamic Self Efficacy (X2) has a value of -2,901 and a significance value of 0.06 at a coefficient $(\alpha)$ of $5 \%$. Because the significance value is $<0.05$, it can be concluded that Islamic Self Efficacy (X2) has a negative and significant effect on Productivity (Z).

2. F-test (Simultan)

The results of the $\mathrm{F}$ test of this study have a coefficient value of 16,729 with a significance value of $0.000<0.05$. These results mean that the independent variables simultaneously have a positive and significant effect on job satisfaction

3. $\mathrm{R}^{2}$ Test

The correlation coefficient $(\mathrm{R})$ of 0763 means that there is a relationship between the dependent variable (job satisfaction) and independent variables(IslamicSelf Esteem. Islamic Self Efficacy, Productivity) of 0763 that have the meaning contribution of independent variables affect the dependent variable worth $54.7 \%$, meanwhile the remaining $45.3 \%$ is dominated by other variables outside the model.

\subsection{Analysis}

1. Path Analysis

a. The direct influence of Islamic Self Esteem on productivity is 0.461 or $46.1 \%$. The magnitude of the indirect effect is $0.399 \times 1.030=0.410$. Based 


\section{$A I C \overline{I E B} \quad$ Annual International Conference \\ on Islamic Economics and Business, 2021}

on the results of the multiple linear tests above, the following equation is obtained:

$\mathrm{Y}=0,250(\mathrm{X} 1)+0,247(\mathrm{X} 2)+0,896(\mathrm{Z})+\mathrm{e}_{2}$

Nilai $\mathrm{e}_{2}=\sqrt{1-R^{2}}=\sqrt{1-0,582}=\sqrt{0,148}=0,385$

So that the regression equation is obtained:

$\mathrm{Y}=-0,250(\mathrm{X} 1)+0,247(\mathrm{X} 2)+0,896(\mathrm{Z})+0,385$

The value of $\mathrm{e}_{1}$ is 0,646 .

b. The direct influence of Islamic Self Efficacy on productivity is -0.465 or $46.5 \%$. The magnitude of the indirect effect is $0.329 \times 1.030=0.339$.

Based on the results of the multiple linear tests above, the following equation is obtained:

$\mathrm{Z}=0,333(\mathrm{X} 1)+-0,402(\mathrm{X} 2)+\mathrm{e}_{1}$

Value of $\mathrm{e}_{1}=\sqrt{1-R^{2}}=\sqrt{1-0,295}=\sqrt{0,705}=0,839$

So that the regression equation is obtained

$\mathrm{Z}=17.631+0,333(\mathrm{X} 1)+-0,402(\mathrm{X} 2)+0,839$

Value of $\mathrm{e}_{2}$ is 0,839 .

2. Sobel Test

a. Productivity can mediate Islamic self-esteem on job satisfaction. Tested with the Sobel test using the formula:

Description:

P3 : Coefficient of mediating variables

P2 : Coefficient of independent variables

Sp2 : Standard error of an independent coefficient

Sp3 : Standard error of mediation coefficient

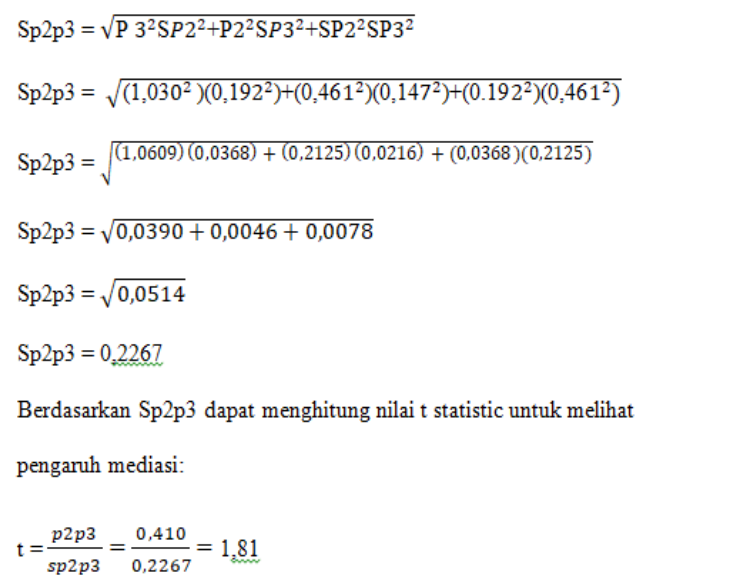

Because the $\mathrm{t}$ count is greater than the $\mathrm{t}$ table, which is 1.68 , it can be concluded that productivity can mediate Islamic Self Esteem on job satisfaction.

b. Productivity can mediate Islamic self-efficacy on job satisfaction. 


$$
\begin{aligned}
& \mathrm{Sp} 2 \mathrm{p} 3=\sqrt{\mathrm{P} 3^{2} \mathrm{SP} 2^{2}+\mathrm{P} 2^{2} \mathrm{SP}^{2}+\mathrm{SP} 2^{2} \mathrm{SP} 3^{2}} \\
& \mathrm{Sp} 2 \mathrm{p} 3=\sqrt{\left(1,030^{2}\right)\left(0,160^{2}\right)+\left(-0,465^{2}\right)\left(0,147^{2}\right)+\left(-0,465^{2}\right)\left(0,147^{2}\right)} \\
& \mathrm{Sp} 2 \mathrm{p} 3=\sqrt{(1,0609)(0,0256)+(0,2162)(0,0216)+(0,2162)(0,0216)} \\
& \mathrm{Sp} 2 \mathrm{p} 3=\sqrt{0,0271+0,0056+0,0056} \\
& \mathrm{Sp} 2 \mathrm{p} 3=\sqrt{0,0383} \\
& \mathrm{Sp} 2 \mathrm{p} 3=0,1888 \\
& \text { Berdasarkan Sp2p3 dapat menghitung nilai t statistic untuk melihat } \\
& \text { pengaruh mediasi: } \\
& \mathrm{t}=\frac{p 2 p 3}{\operatorname{sp} 2 p 3}=\frac{0,399}{0,1888}=2,11
\end{aligned}
$$

Due to t-count greater than t-table, which is 1.68 , it can be concluded that productivity can mediate Islamic Self-Efficacy on job satisfaction.

\subsection{Result}

1. The influence of Islamic self-esteem (X1) on job satisfaction (Y)

Based on the t-test first test is contained in table 4:18 with the coefficient value of $-2,1530$.The level of significance of.038 Moreless than 0.05. So this shows that Islamic Self Esteem has a negative and significant effect on job satisfaction, so $\mathrm{H} 1$ is rejected.

2. The influence of Islamic self-efficacy (X2) on job satisfaction (Y)

Based on the first t-test test contained in table 4.18 with a coefficient value of 2.061, a significance level of 0.047 is smaller than 0.05 . So this shows that Islamic Self Efficacy has a positive and significant effect on job satisfaction, so $\mathrm{H} 2$ is accepted.

3. Productivity Effect (Z) on Job Satisfaction ( $Y$ )

Based on the first t-test test contained in table 4.18 with a coefficient value of 6.986, a significance level of 0.000 is smaller than 0.05 . So this shows that productivity has a positive and significant effect on job satisfaction, so $\mathrm{H} 3$ is accepted.

4. Effect of Islamic Self Esteem (X1) on Productivity (Z)

Based on the second t-test test contained in table 4.19 with a coefficient value of 2.403, a significance level of 0.021 is smaller than 0.05 . So this shows that productivity has a positive and significant effect on job satisfaction, so H4 is accepted.

5. Effect of Islamic Self Efficacy (X2) on Productivity (Z)

Based on the second t-test test contained in table 4.19 with a coefficient value of $-2,901$, a significance level of 0.006 is smaller than 0.05 . So this shows 
that Islamic Self Efficacy has a negative and significant effect on Productivity, so $\mathrm{H} 5$ is rejected.

6. The influence of Islamic Self Esteem (X1) on Job Satisfaction (Y) mediated by Productivity $(Z)$

Judging from the test Path Analysis, the t-count value is 1.81 which is greater than $\mathrm{t}$ table 1.68 , so it can be concluded that Productivity is able to mediate Islamic Self-Esteem on Job Satisfaction so that H6 is accepted.

7. Effect of Islamic Self Efficacy (X2) on Job Satisfaction (Y) mediated by Productivity $(Z)$

Judging from the test Path Analysis, the t-count value is 2.11 greater than $t$ table 1.68, so it is concluded that Productivity is able to mediate Islamic Self Efficacy on Job Satisfaction so that H7 is accepted.

\subsection{CONCLUSION}

Based on the research process, data collection, testing, and the results provided, conclusions can be drawn from the research as follows:

1. The variable Islamic Self Esteem has a negative and significant effect on job satisfaction, so $\mathrm{H} 1$ is rejected. This is contrary to $\mathrm{H} 1$ which states that self-esteem has a positive and significant effect on job satisfaction. It can be concluded that the factor Self Esteem in Kampoeng Kopi Banaran which is embedded in each individual is very low which results in job satisfaction not being obtained properly.

2. The variable Islamic Self Efficacy has a positive and significant effect on job satisfaction, so $\mathrm{H} 2$ is accepted. This is in line with $\mathrm{H} 2$ which states that it reveals that self-efficacy has a positive and significant effect on job satisfaction and that esteem has a positive and significant self- effect on job satisfaction. Selfconfidence is a very important part. The more confident and capable individuals in carrying out tasks, the higher the job satisfaction of employees.

3. Productivity variable positive and significant effect on job satisfaction, so $\mathrm{H} 3$ is accepted. This is in line with $\mathrm{H} 3$ which states that in order to increase productivity for employees, namely by increasing employee welfare. If it refers to Sharia values, for example in the form of a fair salary based on employee performance, the company must pay attention to this again.

4. The variable Islamic Self Esteem has a positive and significant effect on productivity, so $\mathrm{H} 4$ is accepted. This is in line with $\mathrm{H} 4$ which states that there is a positive and significant relationship between Self Esteem and Productivity. Self Esteem is included in the aspect of social support which shows one of the factors that can cause the work productivity of employees in the environment to increase.

5. The variable Islamic Self Efficacy has a negative and significant effect on productivity, so $\mathrm{H} 5$ is rejected. This is contrary to $\mathrm{H} 5$ which states that Work Productivity in terms of Burnout and Self Efficacy shows that there is a positive and significant effect on Productivity.

6. Productivity variable is able to mediate Islamic Self Esteem on Job Satisfaction, so H6 is accepted. This is in line with H6 which states that there is a positive and significant effect between self-esteem and productivity. That work productivity in persons with physical disabilities can be created if they have high self-esteem, behavior, and good social relations using their environment, in the sense that persons with disabilities have self-confidence, are confident in their physical shortcomings, have the courage to do better. 


\section{$A \mathrm{C} \overline{I E B}$ Annual International Conference \\ on Islamic Economics and Business, 2021}

7. Productivity variable is able to mediate Islamic Self Efficacy on Job Satisfaction so that H7 is accepted. This is in line with H7 which states that Self Efficacy on cadre productivity is positive and significant. The results of the study indicate that self-efficacy is an evaluation that a person has of himself, how capable he is of carrying out a certain task to obtain good and maximum results.

\subsection{References}

Arikunto, S. (2006). Prosedut Penelitian Suatu Pendekatan Praktik Edisi Revisi 6. PT Rineka Cipta.

Bawono, A. (2006). Multivariate Analysis dengan SPSS. STAIN Salatiga Press.

Coopersmith, S. (1976). Antecedents Of Self Esteem. W. H. Freeman and Company.

Duwi, P. (2010). Teknik Mudah Dan Cepat Melakukan Analisis Data Penelitian. Gava Media.

Effendi, M. (2002). Manajemen Sumber Daya Manusia. PT Gramedia Widiasarana Indonesia.

Ghozali, I. (2009). Aplikasi Analisis Multivariate Dengan Program SPSS. Universitas Diponegoro.

Hasbuan, \& Malayu, S. P. (2011). Manajemen Sumber Daya Manusia. PT Bumi Aksara.

Herzberg, F., Mausner, B., \& Synderman, B. B. (1958). The motivation to work. Transaction Publishers.

Ismail, A. A. (1998). Menyenai Keyakinan Diri Untuk Berjaya. al - hidayah publisher.

Jafaar, N., \& Tamuri, A. H. (2012). Konsep Efikasi Kendiri Dari Perspektif Islam.

Prosiding AKEPT 2nd Global Annual Young Researchers Conference And

Exhibition. Australian Journal of Basic and Applied Sciences.

Kreitner, K. (2010). Organizational Behavior. McGraw-Hill.

Luthans, F. (2006). Perilaku Organisasi. Edisi Sepuluh PT Andi.

Prawironegoro, D. S. (2001). Manajemen Sumber Daya Manusia Abad 21. Nusantara Consulting.

Raudatussalamah, V. . (2014). Self Esteem dan Self Regulation sebagai unsur penting dalam pendidikan karakter. Semanthic Scholar, 17(2), 8-9.

Sigiro, C. (2005). Analisis Perbedaan Tingkat Kepuasan Kerja ditinjau dari Locus of Control Tipe Kepribadian dan Self Efficacy. Jurnal Bisnis Dan Manajemen, 2.

Sitinjak, T. J. (2006). LISREL. Graha Ilmu.

Soemarso. (2004). Akuntansi Suatu Pengantar. Salemba Empat.

Sutrisno, E. (2014). Manajemen Sumber Daya Manusia. Cetak ke enam Pranada Media Group.

Wibowo, B. K. (2015). Peranan Manajer Sumber Daya Manusia (SDM) Dalam Penarikan (Rekruitmen) di Era Masyarakat Ekonomi ASEAN ( Mea ). Jurnal STIE Semarang, $7(2), 15$.

Winardi. (2001). Motivasi dan Pemotivasian dalam Manajemen. PT Raja Grafindo Persada. 